\title{
STUDI PEMANFAATAN DAUN SIRSAK (Annona murica linn.) SEBAGAI MINUMAN SEDUH DENGAN PENAMBAHAN TEH (Camelia sinensis) SEBAGAI MINUMAN FUNGSIONAL
}

\section{(A study of suorsop leaf utilization as brewed beverage with tea addition as functional drink)}

\author{
Mulyati M. Tahir ${ }^{1 *}$, Jumriah Langkong1), dan Anmar ${ }^{2)}$ \\ *) Program studi Ilmu dan teknologi Pangan, fakultas Pertanian, Universitas Hasanuddin, Makassar, Indonesia \\ 2) Mahasiswa ilmu dan teknologi Pangan, Fakultas pertanian, Universitas hasanuddin, Makassar, Indonesia \\ Korespondensi: p.mulyati@yahoo.com
}

\begin{abstract}
ABSTRAK
(Musaparadisiaca formatypica) adalah salah satu buah yang mengandung cukup banyak serat pencernaan bagi tubuh. Pisang kepok (Musaparadisiaca formatypica) biasanya diolah dengan cara digoreng atau dikukus, pisang memiliki umur simpan yang pendek dan mudah rusak. Karena itu, untuk memperpanjang umur simpan pisang, buah akan diolah menjadi produk kulit buah. Namun, karena warna pisang kurang menarik, penambahan warna akan membuat produk disukai oleh konsumen. Terung belanda (Solanum betaceum cav. Memiliki warna yang cerah dan memiliki kandungan serat yang cukup diolah menjadi kulit buah. Tujuan penelitian ini adalah untuk menemukan kombinasi perlakuan terbaik antara pisang kepok (Musaparadisiaca formatypica) dan terung belanda (Solanum betaceum cav.) konsentrasi gula untuk menghasilkan sifat fisik dan kimia yang baik dan disukai konsumen.Penelitian ini juga untuk mengetahui pengaruh penambahan kadar gula terhadap pisang kulit buah, kulit dan kimia serta terung belanda (Solanum betaceum cav.). adalah A1: pisang kepok (Musaparadisiaca formatypica) dihaluskan 50\%: terung belanda (Solanum betaceum cav) tumbuk 45\%: gula 5\%; A2: 45\%: 40\%: 15\%; A3: 40\%: 35\%: 25\% Kulit buah kemudian diuji secara organoleptik termasuk warna, rasa, rasa dan tekstur dan diuji secara kimia termasuk kadar air, total asam, $\mathrm{pH}$, antosianin dan serat.Hasil penelitian menunjukkan bahwa perlakuan A1: $50 \%$ pisang kepok : terung belanda bubur 45\%: 5\% gula menghasilkan produk kulit buah terbaik dari segi kadar air, asam total, $\mathrm{pH}$, antosianin, serat, aroma, rasa, dan tekstur.
\end{abstract}

Kata Kunci : Kepok pisang, Terung belanda, kulit buah.

\section{ABSTRACT}

Kepok banana (Musaparadisiaca formatypica) is one fruit that contains enough digestive fiber for the body. Kepok banana (Musaparadisiaca formatypica) is usually processed by frying or steaming, bananas have a short shelf life and easily damaged. Therefore, to extend the shelf life of bananas, fruit will be processed into fruit leather products. However, because the color of bananas are less attractive, the color addition will make the product preferred by consumers. Terung belanda (Solanum betaceum cav. has a bright color and has enough fiber content so well processed into fruit leather. The objective of this research was to find the best treatment combination between kepok banana (Musaparadisiaca formatypica) and terung belanda (Solanum betaceum cav.) sugar concentration to produce a good physical and chemical properties and favored by consumers. The research was also to find out the effect of sugar concentration addition to physical, chemical and organoleptic fruit leather banana and terung belanda (Solanum betaceum cav.). Treatment applied was Al: kepok banana (Musaparadisiaca formatypica) mashed 50\%: terung belanda ((Solanum betaceum cav) mashed 45\%: sugar 5\%; A2: 45\%: 40\%: 15\%; A3: 40\%: 35\%: 25\%. Fruit leather is then tested organoleptically including color, flavor, taste and texture and was chemically tested including 
moisture content, total acid, $\mathrm{pH}$, anthocyanin and fiber. The result of the research shows that A1 treatment: $50 \%$ banana porridge: terung belanda porridge 45\%: 5\% sugar produces the best fruit leather product in terms of water content, total acid, $\mathrm{pH}$, anthocyanin, fiber, aroma, taste, and texture.

\section{Keywords : kepok banana, terung belanda, fruit leather}

\section{PENDAHULUAN}

Buah-buahan merupakan salah satu jenis komoditi hasil pertanian yang mengandung vitamin dan mineral yang cukup tinggi sehingga sangat bermanfaat bagi tubuh. Namun, buah-buahan mudah mengalami kerusakan fisik maupun mekanik jika tidak dilakukan penyimpanan pada suhu yang sesuai. Pada dasarnya masyarakat mengkonsumsi buah-buahan secara langsung atau dengan mengolah buah tersebut menjadi juice. Namun seiring berkembangnya teknologi, berbagai macam buah-buahan telah dilakukan penganekaragaman guna memperpanjang umur simpan dari buah tersebut dan menghasilkan produk-produk baru dan inovatif. Salah satu bentuk penganekaragaman buah yaitu dengan mengolah buah menjadi fruit leather.

Fruit leather merupakan produk pangan semi basah yang berbentuk lembaran tipis dan memiliki plastisitas yang baik sehingga mudah digulung. Fruit leather terbuat dari buah-buahan atau sayuran yang mengandung serat cukup tinggi melalui pengeringan dengan diberi bahan tambahan. Terdapat beberapa buah yang mengandung serat yang cukup tinggi dengan kisaran 0,54,29 $\mathrm{g}$ dalam $100 \mathrm{~g}$ bahan yaitu pisang kepok dan terung belanda.

Pisang kepok merupakan salah satu buah yang mengandung serat cukup tinggi sehingga mampu melancarkan system perncernaan didalam tubuh. Pisang kepok merupakan pisang yang biasa dikonsumsi setelah dilakukan pengolahan terlebih dahulu seperti digoreng atau dikukus. Berdasarkan Badan Pusat Statistik selama 2011-2015 rata-rata pertumbuhan produksi pisang di Indonesia sebesar 4,92\%. Pada tahun 2015 total produksi pisang di
Indonesia naik secara signifikan mencapai 7,3 juta ton. Sehingga dengan melimpahnya buah pisang ini dapat dimanfaatkan sebagai produk olahan pangan. Namun, pisang memiliki umur simpan yang cukup singkat sehingga perlu dilakukan pengolahan untuk memperpanjang masa simpannya. Warna pisang yang kurang menarik akan membuat produk kurang disukai sehingga perlu dikombinasikan dengan terung belanda.

Terung belanda merupakan salah satu buah yang mengandung senyawa beta karoten, antosianin dan serat. Beta karoten merupakan salah satu jenis karotenoid yang banyak terdapat pada buah-buahan. Selain beta karoten, terung belanda juga memiliki pigmen warna merah yang tergolong dalam kelompok flavonoid. Pigmen warna merah dalam terung belanda disebut antosianin yang bersifat sebagai antioksidan sehingga dapat menangkal radikal bebas dalam tubuh. Berdasarkan (Statistik, 2013).

Produksi terung belanda di Indonesia pada tahun 2010 adalah 482.305 ton, tahun 2011 adalah 519.481 ton dan tahun 2012 adalah 518.448 ton. Pigmen warna yang terkandung dalam buah terung belanda ini diharapkan mampu membuat warna dari fruit leather semakin disukai. Selain itu, kandungan serat yang cukup tinggi pada buah ini dapat berfungsi untuk melancarkan pencernaan dalam tubuh. Berdasarkan latar belakang tersebut, maka penelitian ini dilakukan untuk mengkombinasikan buah.

Pisang kepok dan terung belanda yang diketahui memiliki kandungan gizi yang tinggi dan memiliki beberapa zat yang penting untuk kesehatan. Penambahan terung belanda juga merupakan salah satu cara untuk mendapatkan warna fruit leather yang menarik sehingga dapat disukai oleh masyarakat dan merupakan salah satu buah yang sering dijumpai di pasar tradisional. 
Keberadaannya yang melimpah membuat buah ini dapat dimanfaatkan menjadi berbagai macam produk olahan. Umur simpannya yang tidak panjang membuat buah ini cepat mengalami kerusakan. Kurangnya pengetahuan masyarakat untuk mengolah pisang membuat buah ini biasanya hanya dikonsumsi secara langsung atau dengan cara dikukus dan digoreng. Kandungan serat yang dimiliki oleh buah ini sangat berfungsi bagi tubuh untuk melancarkan system pencernaan. Selain pisang, terdapat buah yang memiliki kandungan serat yang tinggi yaitu terdapat pada terung belanda. Buah ini kurang dimanfaatkan oleh masyarakat. Biasanya beberapa masyarakat hanya mengolah buah ini dalam bentuk juice. Rasanya yang masam membuat buah ini kurang disukai oleh masyarakat namun warna dari buah ini sangat menarik yaitu berwarna merah. Buah ini sering dijumpai di pasar tradisional bahkan supermarket. Salah satu pengolahan yang tepat untuk kedua buah ini yaitu mengolahnya menjadi fruit leather. Fruit leather ini diharapkan dapat menjadi cemilan sehat yang dapat membantu tubuh untuk melancarkan pencernaan. Selain mengandung serat, fruit leather ini akan mengandung beberapa vitamin yang sangat baik untuk tubuh.

Tujuan yang ingin dicapai dari penelitian ini adalah untuk mengetahui kombinasi perlakuan terbaik antara konsentrasi pisang dan terung belanda serta gula terhadap fruit leather yang dihasilkan dengan sifat fisik dan kimia yang baik serta disukai oleh konsumen dan untuk mengetahui pengaruh penambahan konsentrasi gula terhadap sifat fisik, kimia dan organoleptik fruit leather pisang dan terung belanda.

Kegunaan dari penelitian ini yaitu untuk meningkatkan pemanfaatan buah pisang dan terung belanda agar dapat memperpanjang masa simpan buah tersebut, meningkatkan nilai ekonomis buah pisang dan terung belanda, serta untuk menghasilkan penganekaragaman produk fruit leather dengan kualitas yang baik.

\section{METODOLOGI PENELITIAN}

\subsection{Alat}

Alat-alat yang digunakan pada penelitian ini adalah timbangan analitik, blender, hotplate, gelas kimia, batang pengaduk, loyang, blower, sendok, pisau, saringan, wadah, sendok, spatula karet, thermometer, erlenmeyer, $\mathrm{pH}$ meter, pipet tetes, cawan, oven, desikator.

\subsection{Bahan}

Bahan- bahan yang digunakan dalam penelitian ini adalah the (Camelia sinensis), Daun sirsak (Annona muricata Linn), DPPH, glukosa, air mineral, aluminuim foil, tissue, Metanol, aquadest.

\subsection{Prosedur Penelitian}

Penelitian dilakukan beberapa tahapan sebagai berikut :

\subsubsection{Peneliti pendahuluan}

Penelitian pendahuluan dilakukan untuk menentukan jenis rasio pencampuran antara daun sirsak dan daun teh yang akan digunakan dalam pembuatan minuman seduh daun sirsak dengan penambahan teh berdasarkan rasio pencampuran dan organoleptik dengan parameter pengamatan warna dan aroma.

\subsubsection{Penelitian Utama}

Penelitian utama yaitu menggunakan daun sirsak yang mudah dengan warna hiaju muda atau dari urutan daun ke2 sampai urutan daun ke7 dari ujung pangkal tangkai yang diambil dalam keadaan segar pada waktu masih pagi kemudian dilakukan pencucian menggnakan air mengalir hingga bersih kemudian selanjutnya ditiriskan dan dipotong kecil-kecil untuk memudahkan proses pengeringan dengan menggunakan vakum suhu $65^{\circ} \mathrm{C}$ sampai kering.

Teh yang akan digunakan adalah teh hitam original cap gunung atau olahan daun teh yang tidak menggunakan bahan tambah kemudian dicampurkan berdasarkan rasio atau perlakuan yang telah ditentukan : A0 daun sirsak $100 \%$, A1 daun sirsak $30 \%$ dan 
daun teh $70 \%$, A2 daun sirsak 50\% dan daun teh 50\%, A3 daun sirsak 70\% dan daun teh $30 \%$. setelah itu diambil 2 gram pada masing-masing bahan berdasrkan perlakuan atau rasio dan diseduh dengan air panas 100 ml kemudian di saring untuk pemisahan ampas selanjutnya air dari seduhan dimasukan dalam gelas kemudian dilanjutkan dengan pengujian aktivitas antioksidan, uji kadar air, uji kadar tannin, uji $\mathrm{pH}$, dan uji organoleptik meliputi warna, aroma, rasa.

\subsection{Perlakuan dan Parameter Penelitian} A0= Daun sirsak $100 \%$

$\mathrm{A} 1=30 \%$ Daun sirsak dan daun teh $70 \%$ $\mathrm{A} 2=50 \%$ Daun sirsak dan daun teh $50 \%$ A $3=70 \%$ Daun sirsak dan daun teh $30 \%$

Parameter pengamatan pada penelitian ini yaitu, kadar air, pH, aktivitas antioksidan, kadar tannin, dan uji organoleptik.

\subsubsection{Kadar Air (Sudarmadji dkk., 1997)}

Sampel dihaluskan dan ditimbang sebanyak 2 gram dalam aluminium foil yang telah diketahui beratnya. Kemudian dikeringkan dalam oven pada suhu $105^{\circ} \mathrm{C}$ selama 4 jam. Kemudian didinginkan di dalam desikator selama 15 menit dan ditimbang. Selanjutnya dipanaskan kembali selama 30 menit, didinginkan kembali di dalam desikator dan ditimbang.Perlakuan ini diulangi sampai tercapai berat konstant. Penguarangan berat merupakan banyaknya air yang diuapkan dari bahan, dengan perhitungan :

$\%$ kadar air $=\frac{\text { berat awal-berat akhir }}{\text { berat akhir }} \times 100 \%$

\subsubsection{Nilai $\mathrm{pH}$}

Pengukuran pH (Sudarmadji, Haryono, \& suhardi, 1998) dilakukan dengan menggunakan $\mathrm{pH}$ meter lalu diambil filtrat sampel sekitar $50 \mathrm{ml}$ dan diaduk hingga merata. Dilakukan pengukuran $\mathrm{pH}$ yang hasilnya akan langsung diketahui dengan membaca angka yang ditunjukkan oleh alat.

\subsubsection{Aktifitas Antioksidan Metode DPPH}

Sampel ditimbang sebanyak $0,1 \mathrm{~g}$, Ditambah/Dilarutkan ke dalam metanol 98\% sebanyak $5 \mathrm{ml}$, Divortex hingga homogen, Disentrifuse pada kecepatan 4000rpm selama 10 menit, Diambil $4 \mathrm{ml}$ supernatan sebanyak $4 \mathrm{ml}$ kemudian ditambahkan DPPH 0,2 mM sebanyak $1 \mathrm{ml}$, Didiamkan pada tempat gelap selama 30menit, Diukur absorbansi panjang gelombang $517 \mathrm{Nm}$. Dihitung (\%) Inhibisinya;

$\mathrm{A}=\frac{\text { absorbansi blanko-absorbansi sampel }}{\text { absorbansi blanko }} \times 100 \%$

\subsubsection{Kadar Tannin}

Penentuan kadar total tanin dalam daun sukun dengan menggunakan menggunakan folin. Tahap pengujian diawali dengan preparasi sampel : sampel daun diambil sebanyak 0,05 gr kemudian ditambahkan 25 $\mathrm{ml} \mathrm{H}_{2} \mathrm{O}$ panas kemudian dipipet sebanyak 0,5 $\mathrm{ml}$ dan ditambahkan $\mathrm{H}_{2} \mathrm{O}$ sebanyak 4,5 $\mathrm{ml}$, sampel siap diukur. Sampel sebanyak 5 $\mathrm{ml}$ ditambahkan 0,25 ml Folin dan 0,5 ml $\mathrm{Na}_{2} \mathrm{CO}_{3}$ jenuh kemudian didiamkan selama 30 menit. Diukur panjang gelombang 680 nm.

$$
A=F P x X(m g) \times \frac{100}{\text { beratsampel }(m l)}
$$

\subsubsection{Uji Organoleptik}

Uji organoleptik (Rampengan, 1985) dilakukan untuk mengetahui tingkat kesukaan atau kelayakan suatu produk agar dapat diterima oleh panelis (konsumen). Metode pengujian yang dilakukan adalah metode hedonik (uji kesukaan) meliputi rasa, warna dan aroma. Dalam metode hedonik ini, panelis (konsumen) diminta memberikan penilaian berdasarkan tingkat kesukaan. Skor yang digunakan adalah 5 (sangat suka), 4 (suka), 3 (agak suka),2 (tidak suka), dan 1 (sangat tidak suka). 


\section{HASIL DAN PEMBAHASAN}

\subsection{Kadar Air}

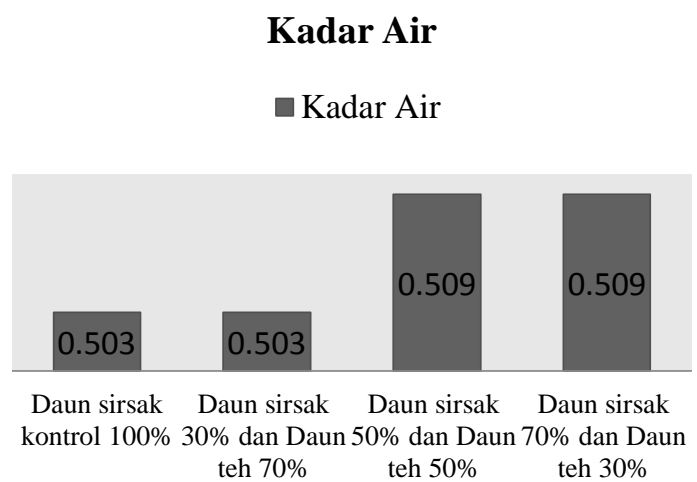

Gambar 01. Hasil uji kadar air terhadap minuman daun sirsak dengan penambahan teh

Hasil uji kadar air yang diperoleh berdasarkan (gambar 01) relatif sama untuk setiap perlakuan, perlakuan A0 dengan konsentrasi daun sirsak $100 \%$ memiliki hasil yaitu $0,503 \%$ sedangkan perlakuan A1 konsentrasi daun sirsak $30 \%$ dan daun teh $70 \%$ memiliki hasil yaitu 0,503 , sedangkan hasil kadar air tertinggi pada perlakuan A2 dan A3 yaitu A2 konsentrasi daun sirsak $50 \%$ dan daun the $50 \%$ memiliki hasil yaitu 0,509\%, A3 konsentrasi daun sirsak $70 \%$ dan daun teh $30 \%$ memiliki hasil yaitu $0,509 \%$.

Hasil uji t pada perlakuan A0 (daun $100 \%$ ) dan A1 (daun sirsak30\% dan daun teh70\%) diperoleh hasil tidak berbda nyata, A0 (daun 100\%) dan A2 (daun sidak 50\% dan daun teh $50 \%$ ) diperoleh hasil tidak berbeda nyata, A0 (daun 100\%) dan A3 (daun sirsak $70 \%$ dan daun the $30 \%$ ) diperoleh hasil tidak berbeda nyata. Sedangkan perlakuan A1 (daun sirsak $70 \%$ dan daun the $30 \%$ ) dan A2 (daun sirsak $50 \%$ dan daun the $50 \%$ ) berbeda berbeda nyata, A1 (daun sirsak $70 \%$ dan daun the $30 \%$ ) dan A3 (daun sirsak $70 \%$ dan daun the 30\%) tidak berbeda nyata serta perlakuan A2 (daun sirsak 50\% dan daun teh 50\%) dan A3 (daun sirsak $70 \%$ dan daun teh 30\%) diperoleh hasil berbeda nyata.

\section{$3.2 \mathrm{pH}$}

$$
\square \mathrm{pH}
$$

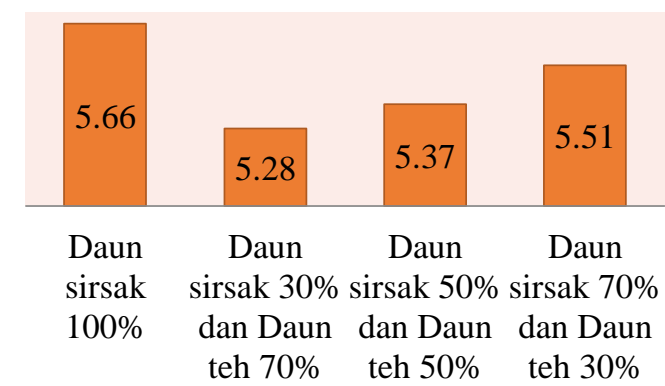

Gambar 02. Hasil Ph Terhadap Minuman Daun

Hasil analisa $\mathrm{pH}$ minuman daun sirsak dengan penambahan teh meunjukan bahwa perlakuan A0 dengan konsentrasi daun sirsak $100 \%$ dengan nilai $\mathrm{pH}$ tertinggi yaitu 5,66, A2 dengan konsentrasi daun teh 50\% dan daun sirsak $50 \%$ yaitu 5,37 perlakuan A3 dengan konsentrasi $70 \%$ daun sirsak dan $30 \%$ daun teh yaitu 5,51 dan $\mathrm{pH}$ terendah pada perlakuan A1 dengan konsentrasi $30 \%$ daun sirsak dan $70 \%$ teh yaitu 5,28. pH diperoleh pada minuman daun sirsak dengan penambahan teh meiliki nilai stabil pada A3 dan A2 meningkat namun mengalami penurunan pada perlakuan A1 namun jika nilai yang dihasilkan dalam keadaan normal karena antioksidan masih dapat bekerja.Kisaran $\mathrm{pH}$ Antioksidan yaitu 6-8 jika rendah maka kemampuan ion hidrogen dalam medium yang berfungsi sebagai pendonor semakin berkurang, dengan meningkatnya $\mathrm{pH}$ maka konsentrasi ion Hidrogen dalam medium menurun sehingga mulai terjadi pelepasan elektron oleh senyawa fenolik. Hal ini sesuai dengan (Shahidi, 1997) bahwa antioksidan dari kelompok senyawa fenolik berfungsi sebagai donor hidrogen yang akan menstabilkan senyawa radikal. Pada $\mathrm{pH}$ rendah konsentrasi hidrogen dalam medium meningkat sehingga menekan pelepasan ion hidrogen dari senyawa fenolik.

Hasil uji t pada perlakuan A0 (daun $100 \%$ ) dan A1 (daun sirsak 30\% dan daun teh70\%) diperoleh hasil berbeda nyata, A0 (daun 100\%) dan A2 (daun sidak 50\% dan daun teh $50 \%$ ) diperoleh hasil berbeda nyata, 
A0 (daun 100\%) dan A3 (daun sirsak70\% dan daun the 30\%) diperoleh hasil tidak berbeda nyata. Sedangkan perlakuan A1 (daun sirsak $70 \%$ dan daun the 30\%) dan A2 (daun sirsak $50 \%$ dan daun the 50\%) diperoleh hasil tidak berbeda nyata, A1 (daun sirsak $70 \%$ dan daun the 30\%) dan A3 (daun sirsak $70 \%$ dan daun the 30\%) diperoleh hasil tidak berbeda nyata.

\subsection{Aktivitas Antioksidan}

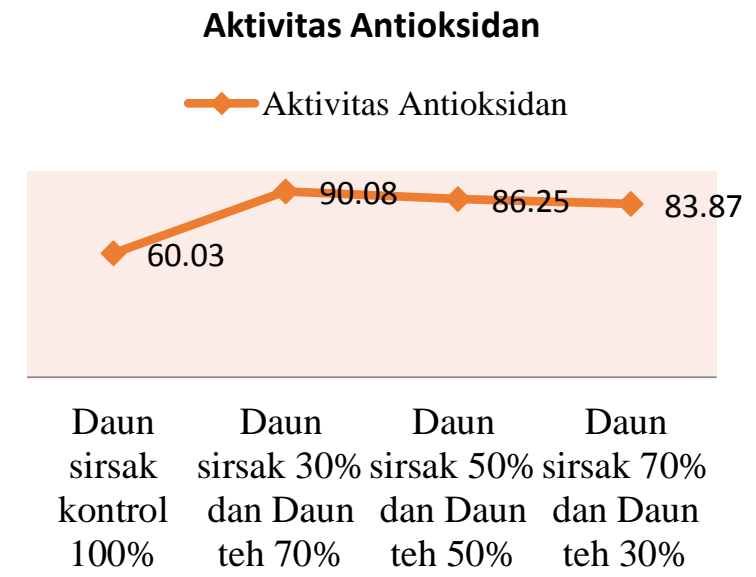

Gambar 03. Hasil uji aktivitas antioksidan terhadap minuman daun sirsak dengan penambahan teh

Hasil uji aktifitas antioksidan yang diperoleh berdasarkan (gambar 07) relatif sama untuk setiap perlakuan, perlakuan A0 dengan konsentrasi daun sirsak $100 \%$ memiliki hasil yaitu $60,03 \%$ sedangkan perlakuan A1 konsentrasi daun sirsak $30 \%$ dan daun teh $70 \%$ memiliki hasil tertinggi yaitu 90,08, A2 konsentrasi daun sirsak 50\% dan daun the $50 \%$ memiliki hasil yaitu $86,25 \%$, A3 konsentrasi daun sirsak $70 \%$ dan daun the $30 \%$ memiliki hasil terendah yaitu $83,87 \%$. Hasil pengujian antioksidan pada penelitian ini menunjukkan bahwa antioksidan alami yang terdapat pada minuman seduh yang dihasilkan kadar aktivitas antioksidannya akan bertambahapabila dilakukan penambahan daun teh, semakin tinggi konsentrasi daun tehyang ditambahkan maka aktivitas antioksidan cenderung akan tinggi. Hal ini sesuai (Medikasari, 2000) bahwa penggunaan teh dapat menigatkatkan kadar aktifitas antioksiidan karena teh mengandung antioksidan tinggi sehingga akan meningkatkan aktivitas antioksidan yang ditambahkan dalam bahan.

Hasil uji t perlakuan A0 (daun sirsak $100 \%$ ) dan A1 (daun sirsak 30\% dan daun teh70\%) diperoleh hasil berbeda nyata, A0 (daun sirsak 100\%) dan A2 (daun sirsak $50 \%$ dan daun teh 50\%) diperoleh hasil berbeda nyata, A0 (daun sirsak 100\%) dan A3 (daun sirsak $70 \%$ dan daun teh30 \%) diperoleh hasil tidak berbeda nyata. Sedangkan perlakuan A1 (daun sirsak 30\% dan daun teh 70\%) dan A2 (daun sirsak 50\% dan daun teh $50 \%$ ) tidak berbeda nyata, A1 (daun sirsak30\% dan daun teh $70 \%$ ) dan A3 (daun sisak $70 \%$ dan daun teh30\%) tidak berbeda nyata serta perlakuan A2 (daun sirsak 50\% dan daun teh 50\%) dan A3 (daun sirsak $70 \%$ dan daun teh $30 \%$ ) diperoleh hasil tidak berbeda nyata.

\subsection{Kadar Tannin}

\section{Kadar Tannin}

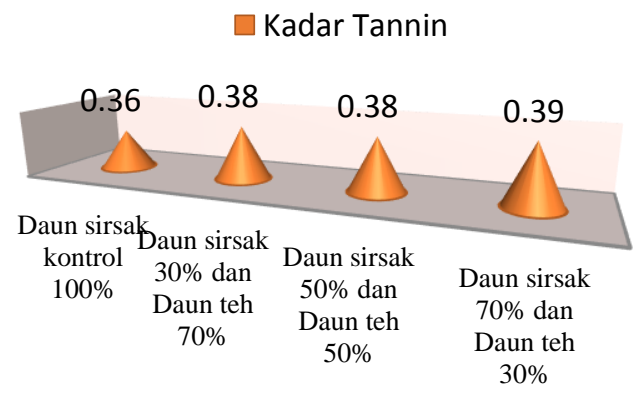

Gambar 04. Hasil uji kadar tannin terhadap minuman daun sirsak dengan penambahan the.

Berikut contoh penulisan tabel dan gambar.

Hasil uji kadar tannin menunjukkan bahwa perlakuan A3 konsentrasi daun sirsak $70 \%$ dan daun teh $30 \%$ dengan hasil tertinggi yaitu $0,39 \%$, dan perlakuan A1 konsentrasi daun sirsak $30 \%$ dan daun teh $70 \%$ yaitu $0,38 \%$, A2 konsentrasi daun sirsak $50 \%$ dan daun teh $50 \%$ yaitu $0,38 \%$ sedangkan kadar tannin terendah pada perlakuan A0 konsentrasi 100\% daun sirsak dengan hasil 0,36. Hal ini disebabkan karena 
tanin memiliki aktivitas biologis sebagai antioksidan sehingga kandungan tanin dalam daun sirsak akan berpengaruh pada aktivitas antioksidan. Semakin tinggi jumlah daun sirsak yang digunakan maka semakin tinggi pula kadar tanin yang dihasilkan. Hal ini disebabkan karena tannin merupakan bagian dari senyawa polifenol yang memiliki aktivitas penangkal radikal bebas. Hal ini sesuai dengan (Hagerman, 1998) dan (Harborne, 1987) bahwa tanin tergolong senyawa polifenol.Tanin secara umum didefinisikan sebagai senyawa polifenol yang memiliki beratmolekul cukup tinggi (lebih dari 1000) dan dapat membentuk kompleks denganprotein.Tanin juga dapat berfungsi sebagai antioksidan biologis.

Hasil uji t perlakuan A0 (daun sirsak $100 \%$ ) dan A1 (daun sirsak 30\% dan daun teh70\%) diperoleh hasil tidak tidak berbeda nyata, A0 (daun sirsak 100\%) dan A2 (daun sirsak $50 \%$ dan daun teh $50 \%$ ) diperoleh hasil tidak berbeda nyata, A0 (daun sirsak $100 \%$ ) dan A3 (daun sirsak70\% dan daun teh30\%) diperoleh hasil tidak berbeda nyata. Sedangkan perlakuan A1 (daun sirsak 30\% dan daun teh $70 \%$ ) dan A2 (daun sirsak 50\% dan daun teh 50\%) tidak berbeda nyata, A1 (daun sirsak30\% dan daun teh $70 \%$ ) dan A3 (daun sisak $70 \%$ dan daun teh30\%) tidak berbeda nyata serta perlakuan A2 (daun sirsak 50\% dan daun teh 50\%) dan A3 (daun sirsak $70 \%$ dan daun teh30\%) diperoleh hasil tidak berbeda nyata.

\subsection{Uji Organoleptik}

\subsubsection{Warna}

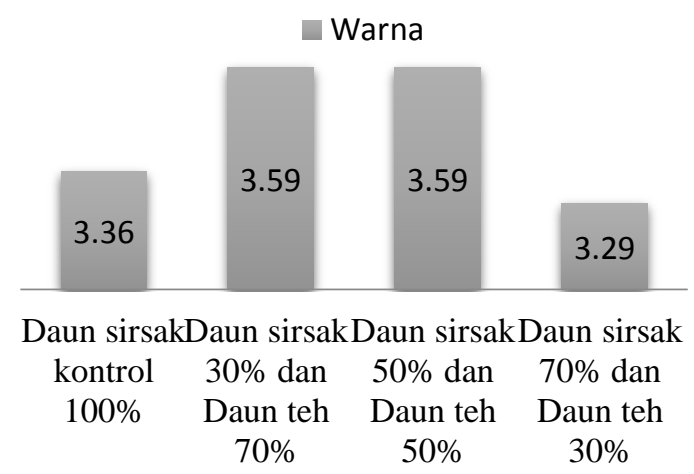

Gambar 05. Hasil Organoleptik warna terhadap minuman daun sirsak dengan penambahan teh
Hasil uji organoleptik menunjukkan rata rata panelis menyukai warna pada minuman daun sirsak dengan penambahan teh. Kecuali pada perlakuan A3 dengan penambahan $30 \%$ daun tehyang rendah menyebabkan warna pada minuman menjadi pucat dan pudar atau tidak pekat dan cerah. Hal ini dapat dilihat pada perlakuan A1 dan A2 yang memiliki nilai yang tertingggi dan sama, perlakuan A1 konsentrasi daun sirsak $30 \%$ dan daun teh $70 \%$ dengan nilai $3,59 \%$, A2 konsentrasi daun sirsak $50 \%$ dan daun teh $50 \%$ dengan nilai 3,59\%, A0 konsentrasi daun sirsak $100 \%$ dengan nilai 3,36\% dan rata rata disukai panelis. Warna hijau dan merah yang dihasilakan merupakan senyawa alami yang terkandung dalam daun sirsak dan teh. Senyawa alami tersebut merupakan tanin yang dimiliki oleh daun sirsak berperan dalam pemberian warna pada minuman. Hal ini sesuai dengan (Shahidi, 1997) bahwa kandungan tanin dalam bahan dapat digunakan sebagai pedoman mutu, karena tanin memberikan kemantapan warna pada bahan, tanin memiliki peranan biologis yang kompleks. Hal ini dikarenakan sifat tanninyang sangat kompleks mulai dari pengendap protein hingga pengkelat logam.

Hasil uji t perlakuan A0 (daun sirsak $100 \%$ ) dan A1 (daun sirsak 30\% dan daun teh70\%) diperoleh hasil tidak tidak berbeda nyata, A0 (daun sirsak 100\%) dan A2 (daun sirsak $50 \%$ dan daun teh $50 \%$ ) diperoleh hasil tidak berbeda nyata, A0 (daun sirsak $100 \%$ ) dan A3 (daun sirsak $70 \%$ dan daun teh30 \%) diperoleh hasil tidak berbeda nyata. Sedangkan perlakuan A1 (daun sirsak 30\% dan daun teh 70\%) dan A2 (daun sirsak 50\% dan daun teh 50\%)tidak berbeda nyata, A1 (daun sirsak30\% dan daun teh $70 \%$ ) dan A3 (daun sisak $70 \%$ dan daun teh30\%) tidak berbeda nyata serta perlakuan A2 (daun sirsak 50\% dan daun teh 50\%) dan A3 (daun sirsak $70 \%$ dan daun teh30\%) diperoleh hasil tidak berbeda nyata. 


\subsubsection{Aroma}

\section{Aroma}

Aroma

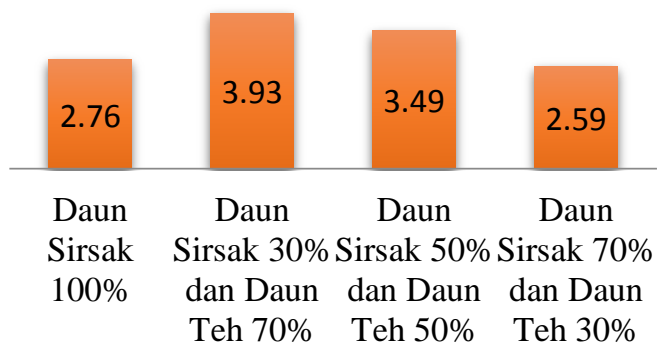

Gambar 06. Hasil Organoleptik Aroma terhadap minuman daun sirsak dengan penambahan teh.

Hasil analisa menunjukkan bahwa perlakuan A1 konsentrasi daun sirsak $30 \%$ dan daun teh $70 \%$ meiliki nilai tertinggi yaitu 3,93 dan terendah pada perlakuan perlakuan perlakuan A3 konsentrasi daun sirsak $70 \%$ dan daun teh $30 \%$ yaitu 2,59.

Hal ini disebabkan daun teh yang dapat memberikan aroma harum pada minuman daun sirsak yang dihasilkan. Hal ini sesuai dengan (Shahidi, 1997) bahwa dalam teh tanin adalah kandungan dari fenolik kompleks mempunyai berat molekul 5006000 Da. Kandungan tanin dalam teh dapat digunakan sebagai pedoman mutu, karena tanin memberikan kemantapan warna, aroma, dan rasa

Hasil uji $t$ perlakuan A0 (daun sirsak $100 \%$ ) dan A1 (daun sirsak 30\% dan daun teh70\%) diperoleh hasil tidak tidak berbeda nyata, A0 (daun sirsak 100\%) dan A2 (daun sirsak $50 \%$ dan daun teh $50 \%$ ) diperoleh hasil tidak berbeda nyata, A0 (daun sirsak $100 \%$ ) dan A3 (daun sirsak70\% dan daun teh30 \%) diperoleh hasil tidak berbeda nyata. Sedangkan perlakuan A1 (daun sirsak 30\% dan daun teh 70\%) dan A2 (daun sirsak $50 \%$ dan daun teh 50\%)tidak berbeda nyata, A1 (daun sirsak $30 \%$ dan daun teh $70 \%$ ) dan A3 (daun sisak 70\% dan daun teh30\%) berbeda nyata serta perlakuan A2 (daun sirsak 50\% dan daun teh 50\%) dan A3 (daun sirsak 70\% dan daun teh30\%) diperoleh hasil tidak berbeda nyata.

\subsubsection{Rasa}

\section{Rasa}

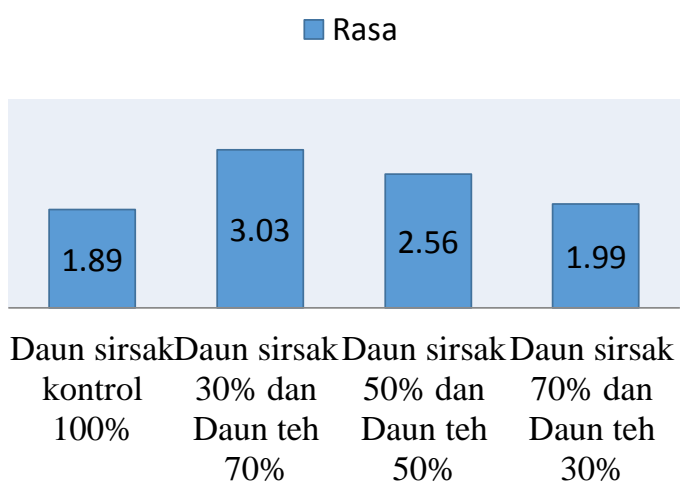

Gambar 07. Hasil Organoleptik Rasa terhadap minuman daun sirsak dengan penambahan teh.

Hasil organoleptik terhadap rasa produk minuman seduh daun sirsak dengan penambah daun teh menunjukkan bahwa perlakuan A0 kurang disukai panelis, sedangkan perlakuan A1 lebih disukai panelis dibandinkang dengan perlakuan lain karena pengujian organoleptik terhadap rasa diperoleh nilai tertinggi pada perlakuan A1 konsentrasi daun sirsak $30 \%$ dan daun teh $70 \%$ dengan nilai 3,03\% sedangkan dengan hasil terendah pada perlakuan A3 konsentrasi daun sirsak $100 \%$ dengan nilai 1,89\%, A2 konsentrasi daun sirsak $50 \%$ daun teh $50 \%$ yaitu $2,56 \%$, A3 konsentrasi daun sirsak $70 \%$ dan daun teh $30 \%$ dengan nilai $1,99 \%$. Hal ini disebabkan karena pada daun sirsak mengandung senyawa tannin yangbersifat sepat dan pahit sehingga dalam penelitian perlakuan A0 tanpa daun teh rasa sepat dari daun sirsak lebih terasa. Rasa sepat dan pahit pada daun disebabkan karena adanya senyawa alami pada bahan yang memiliki pengaruh terhadap rasa suatu produk. Hal ini sesuai dengan (Shahidi, 1997) bahwa tannin merupakan suatu senyawa turunan flavonoid yang memberikan rasa sepat pada bahan. Hasil uji t perlakuan A0 (daun sirsak 100\%) dan A1 (daun sirsak $30 \%$ dan daun teh70\%) 
diperoleh hasil berbeda nyata, A0 (daun sirsak 100\%) dan A2 (daun sirsak 50\% dan daun teh 50\%) diperoleh hasil tidak berbeda nyata, A0 (daun sirsak 100\%) dan A3 (daun sirsak $70 \%$ dan daun the $30 \%$ ) diperoleh hasil tidak berbeda nyata. Sedangkan perlakuan A1 (daun sirsak 30\% dan daun teh $70 \%$ ) dan A2 (daun sirsak $50 \%$ dan daun teh $50 \%$ ) tidak berbeda nyata, A1 (daun sirsak $30 \%$ dan daun teh $70 \%$ ) dan A3 (daun sisak $70 \%$ dan daun teh30\%) tidak berbeda nyata serta perlakuan A2 (daun sirsak $50 \%$ dan daun teh 50\%) dan A3 (daun sirsak 70\% dan daun teh30\%) diperoleh hasil tidak berbeda nyata.

\section{KESIMPULAN}

Kesimpulan dari penelitian pembuatan minuman daun sirsak dengan penambahan Daun Teh yaitu :

1. Dari beberapa perlakuan berikut A0, A1, A2, dan A3 perlakuan A1 merupakan perlakuan terbaik dengan nilai tertinggi.

2. Perlakuan terbaik pada pembuatan minuman seduh daun sirsak dengan penambahan teh terdapat pada perlakuan A1 konsentrasi daun sirsa 30\% dan Daun teh $70 \%$ dengan nilai tertinggi dari pengujian aktivitas aktiosidan dengan nilai $90.08 \%$, Pengujian Organoleptik Aroma yaitu $3.93 \%$, Warna yaitu $3.53 \%$, Rasa yaitu $3.03 \%$.

\section{DAFTAR PUSTAKA}

Hagerman. (1998). Tannins Chemistry.

Harborne. (1987). Metode Fitokimia Penuntun Cara Modern Menganalisis Tumbuhan. Bandung: UI Press.

Medikasari. (2000). Bahan Tambahan Makanan : Fungsi dan Penggunaannya Dalam Makanan. Bogor: Institut Pertanian Bogor.

Rampengan. (1985). Dasar-dasar Pengawasan Mutu Pangan. Badan Kerja sama Perguruan Tinggi Negeri Indonesia Bagian Timur. Ujing Pandang.

Rohimah. (2016). Outlook Komoditas
Pertanian Sub Sektor Hortikultura . Pusat Data Dan Sistem Informasi Pertanian.

Shahidi. (1997). Natural Antioxidants Chemistry, Health Effects and Applications. Illinois: AOCS Press.

Statistik, B. P. (2013). Pengembangan Model Sosial Analisis Spasial Angka Harapan Hidup Penduduk IndonesiaHasil Sensus Penduduk 2010. Jakarta: Sub direktorat Pengembangan Model Statistik BPS.

Sudarmadji, Haryono, \& suhardi. (1998). Prosedur Analisa Untuk Bahan Makanan dan Pertanian. Bandung: Penerbit Angkasa. 